\title{
Könyvismertetés: A Cica, a Kisveréb, Hangya Úr és a koronavírus Járványos tanmese nagyovisoknak és kisiskolásoknak
}

\author{
Book review: The Kitten, the Sparrow, Mr. Ant and the coronavirus \\ Epidemic fairy tale for kindergartener and school children
}

Ismertető: $\quad$ Bíróné Asbóth Katalin $\square$

Heim Pál Országos Gyermekgyógyászati Intézet Módszertani Igazgatóság, Budapest

Beküldve: $\quad$ 2020. 07. 22.

doi: $\quad$ 10.24365/ef.v61i3.613

Kulcsszavak: koronavírus; járvány; gyermekmese; egészségértés

Keywords: coronavirus; epidemic; children's fairy tale; health literacy

\begin{abstract}
A gyermekekhez közelálló, mindennapjaikból ismerős szereplőket megjelenítő, bájos mese és rajzos illusztráció könnyed hangon hozza gyermekek közelébe az egyáltalán nem könnyű témát. A sok évtizedes infektológiai, védőoltási és gyermekgyógyászati gyakorlattal rendelkező szerző játékos hangvételű története a Cicáról, Kisverébről, Hangya Úrról és Pankáról - egy mesesorozat első köteteként - segíti a gyermekek értelmi, fogalmi, érzelmi fejlődését. A gyermeki világhoz illeszkedő, kedves rajzok, játé-
\end{abstract}

kos magyarázatok támogatják a gyermekek szorongástól mentes, egészségtudatos gondolkozásának kialakulását, egészségértésük fejlődését.

A mesés történet könnyebbé teszi a felnőttek számára is, hogy ezekről a témákról a gyermeki világba helyezkedve, a gyermekek számára érthető, befogadható nyelven tudjanak beszélgetni, a kérdéseikre válaszolni. Jó szívvel ajánljuk a könyvecskét mindazoknak, akik gyermekekkel foglalkoznak.

A könyvet írta: Dr. Mészner Zsófia, rajzolta: Szabó Gabriella

Kiadja: Uro-Medic Kiadó Budapest, 2020

A kiadvány nyomtatásban megrendelhető a kiadótól, illetve letölthető a következő helyekről:

http://www.hgye.hu/index.php?id=3\&cid=308

https://mave.hu/uploads/file/Covidmese\%20Pdf\%2020200517.pdf

További ajánlott cikkek a témában:

https://gyogyhirek.hu/koronavirus-jarvany-miatti-karanten-hatasa-gyermekek-lelki-allapotara/

https://gyogyhirek.hu/karanten-alatti-higienes-szabalyok/ 